\title{
A NEW RECORD OF DIODON HYSTRIX (ACTINOPTERYGII: TETRAODONTIFORMES: DIODONTIDAE) IN THE MEDITERRANEAN SEA
}

\author{
Francesc ORDINES ${ }^{1 *}$, Salud DEUDERO ${ }^{1}$, Jaime SINTES-VILA ${ }^{2}$, Valerio SBRAGAGLIA ${ }^{3,4}$, \\ Ronald FRICKE 5 , and Ernesto AZZURRO ${ }^{3,6}$ \\ ${ }^{1}$ Instituto Español de Oceanografía - Centre Oceanogràfic de les Balears, Palma, Spain \\ ${ }^{2}$ Centre Balear de Biologia Aplicada, Palma, Spain \\ ${ }^{3}$ ISPRA, Institute for Environmental Protection and Research, Livorno, Italy \\ ${ }^{4}$ Department of Biology and Ecology of Fishes, Leibniz-Institute of Freshwater Ecology and Inland Fisheries, Berlin,
} Germany

${ }^{5}$ Im Ramstal 76, 97922 Lauda-Königshofen, Germany

${ }^{6}$ Stazione Zoologica Anton Dohrn (SZN), Naples, Italy

Ordines F., Deudero S., Sinte-Vila J., Sbragaglia V., Fricke R., Azzurro E. 2018. A new record of Diodon hystrix (Actinopterygii: Tetraodontiformes: Diodontidae) in the Mediterranean Sea. Acta Ichthyol. Piscat. 48 (4): 403-407.

\begin{abstract}
The spot-fin porcupinefish, Diodon hystrix Linnaeus, 1758, was first recorded in the Mediterranean by Torchio (1963), from the Gulf of Taranto, Italy. There have been no subsequent records, from this sea, ever since. In this paper, we report a new record of $D$. hystrix from the Balearic Islands, western Mediterranean, fifty-five years after the first record. The fish individual was caught during a spearfishing competition. The social networks and the WhatsApp instantaneous messenger proved to be useful tools for the rapid contact with the scientists who are now reporting this record. In view of the fast growth and spreading of other populations of exotic species in the Mediterranean, fostering the communication between recreational fishers and scientists through these types of digital tools could help in monitoring of the natural environment.
\end{abstract}

Keywords: porcupinefish, Balearic Islands, recreational fishery, citizen science, social networks, WhatsApp

\section{INTRODUCTION}

The porcupinefish family Diodontidae contains seventeen species in seven genera (Fricke et al. 2018). The family is widely distributed in tropical and temperate marine areas of the Indo-Pacific and Atlantic Oceans (Leis 2006). Six species of Diodontidae, representing two genera, occur in the Atlantic Ocean (Leis 2016). However, only three of them have been recorded from the Mediterranean Sea: Diodon hystrix Linnaeus, 1758, Chilomycterus reticulatus (Linnaeus, 1758), and Chilomycterus spinosus mauretanicus (Le Danois, 1954) (see Torchio 1963, Follesa et al. 2009, Garrido et al. 2014, respectively). The fourth porcupinefish species, native of the Indo-Pacific area, Cyclichthys spilostylus (Leis et Randall, 1982), also occurs in the Mediterranean, due to the phenomenon of the Lessepsian migration through the Suez Canal (Golani 1993, Erguden et al. 2012). Mediterranean porcupinefish records are based on occasional observations, whilst no evidence of established populations exists and the entire family is considered as vagrant (Relini 2010, Golani et al. 2017). The previous localities where $D$. hystrix have been recorded in the North-eastern Atlantic and the Mediterranean are: the Atlantic coast of southern Iberian Peninsula (and possibly Valencia on the Mediterranean coast of Spain), Atlantic coast of Morocco, the Atlantic archipelagos of Madeira and Azores, and the Gulf of Taranto in southern Italy, central Mediterranean (Gonçalves 1941, di Noronha and Sarmento 1948, Lozano y Rey 1952, Dollfus 1955, Torchio 1963, Tortonese 1986, Santos et al. 1997) (Fig. 1); another specimen found in East Anglia, UK was based on an aquarium release (Ellis 2006).

Records of D. hystrix from Turkey (Akşıray 1954) are considered unreliable (Bilecenoglu et al. 2002). The observation of D. hystrix from the Canary Islands (Brito et al. 2002) was erroneous and based on Diodon eydouxii Brisout de Barneville, 1846 (see Azevedo et al. 2004). 
In this paper, we report a new capture of the spotfin porcupinefish, D. hystrix, in the Mediterranean Sea. Although the spot-fin porcupinefish is a circumtropical species, widely distributed in the Atlantic, Indian, and Pacific oceans (Leis 2006), it is currently considered as 'not established' or 'casual' in the Mediterranean Sea (Zenetos et al. 2012) where, to the best of our knowledge, it has only been recorded once before, by Torchio (1963), from the Gulf of Taranto, the Ionian Sea.

\section{MATERIAL AND METHODS}

On 19 November 2016, an adult specimen of Diodon hystrix was captured during a spearfishing competition along the north-eastern coast of Menorca, Balearic Islands $\left(39^{\circ} 54^{\prime} 37^{\prime \prime} \mathrm{N}, 004^{\circ} 17^{\prime} 49^{\prime \prime} \mathrm{E}\right)$ (Fig. 1). The meristic and morphometric characters were recorded on the fresh specimen. The taxonomic identification was based on Leis (2001, 2006, 2016). Unfortunately, the individual was lost due to an electricity failure that affected the freezer where it was stored. The only remains left of it is one two-rooted body spine.

\section{RESULTS}

The specimen was a large individual weighing 7800 $\mathrm{g}$ and measuring $640 \mathrm{~mm}$ in total length. Morphometric measurements are presented in Table 1. The individual was positively identified as Diodon hystrix due to the coincidence of its characters with those described in Leis $(2006,2016)$ for this species. The fish presented a wide and hard body covered with erectile long spines with two large roots under the skin; dorsal and anal fins with 14 and 16 rays, respectively; dorsal fin in posterior position opposing anal fin, both fins rounded; caudal fin rounded; no pelvic fins; pectoral fin with 23 rays; wide and blunt head; large mouth with a beak-like structure without a median suture dividing the jaws into left and right halves; one spine on the dorsal surface of the caudal peduncle and eighteen spines from lower jaw to anus; colour light to dark brown dorsally, with small black spots, and white ventrally; all fins heavily spotted (Fig. 2).
Table 1

Morphometric measurements of Diodon hystrix recorded in Menorca (Balearic Islands, western Mediterranean)

\begin{tabular}{lrr}
\hline \multirow{2}{*}{\multicolumn{1}{c}{ Morphometric character }} & \multicolumn{2}{c}{ Value } \\
\cline { 2 - 3 } & {$[\mathrm{mm}]$} & {$[\% \mathrm{TL}]$} \\
\hline Total length (TL) & 640 \\
Standard length & 554 & 86.6 \\
Head length & 173 & 27.0 \\
Head width & 218 & 34.1 \\
Head depth & 137 & 21.4 \\
Eye diameter & 28 & 4.4 \\
Snout length & 59 & 9.2 \\
Gill opening length & 55 & 8.6 \\
Body depth & 135 & 21.1 \\
Interorbital length & 140 & 21.9 \\
Postorbital length & 86 & 13.4 \\
Pectoral fin height & 92 & 14.4 \\
Pre-pectoral length & 195 & 30.5 \\
Pectoral fin base length & 85 & 13.3 \\
Pre-dorsal length & 390 & 60.9 \\
Dorsal fin base length & 45 & 7.0 \\
Dorsal fin height & 82 & 12.8 \\
Pre-anal length & 410 & 64.1 \\
Anal fin base length & 48 & 7.5 \\
Anal fin height & 80 & 12.5 \\
Pre-caudal length & 554 & 86.6 \\
Caudal peduncle length & 111 & 17.3 \\
Caudal peduncle depth & 37 & 5.8 \\
Caudal fin length & 87 & 13.6 \\
\hline
\end{tabular}

\section{DISCUSSION}

In the last few years an increasing number of 'newcomers' (sensu Evans et al. 2015) has been documented in the Mediterranean Sea (Rilov and Galil 2009, Galil et al. 2015). The geographical expansion of thermophilic species is a global phenomenon, and one of the most direct consequences of climate change on marine species (Parmesan and Yohe 2003, Sunday et al. 2012).

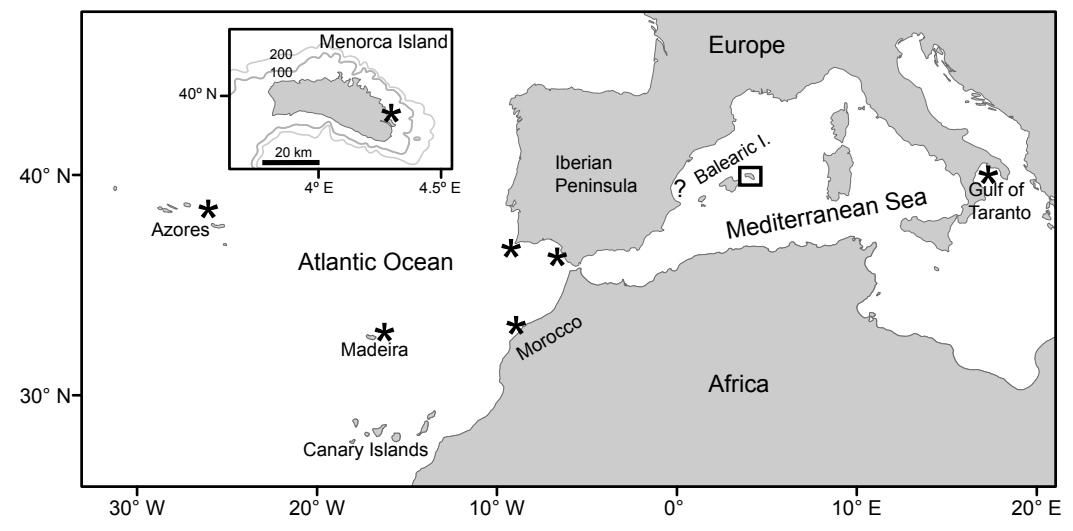

Fig. 1. Map showing the previous records of Diodon hystrix in the northeast Atlantic and Mediterranean (see references in the main text); the inset shows the location of the presently reported new record in Menorca, Balearic Islands; starlike symbols indicate the location of confirmed records; question mark near the Mediterranean coast of the Iberian Peninsula indicates the record with uncertain origin mentioned in Lozano y Rey (1952) 

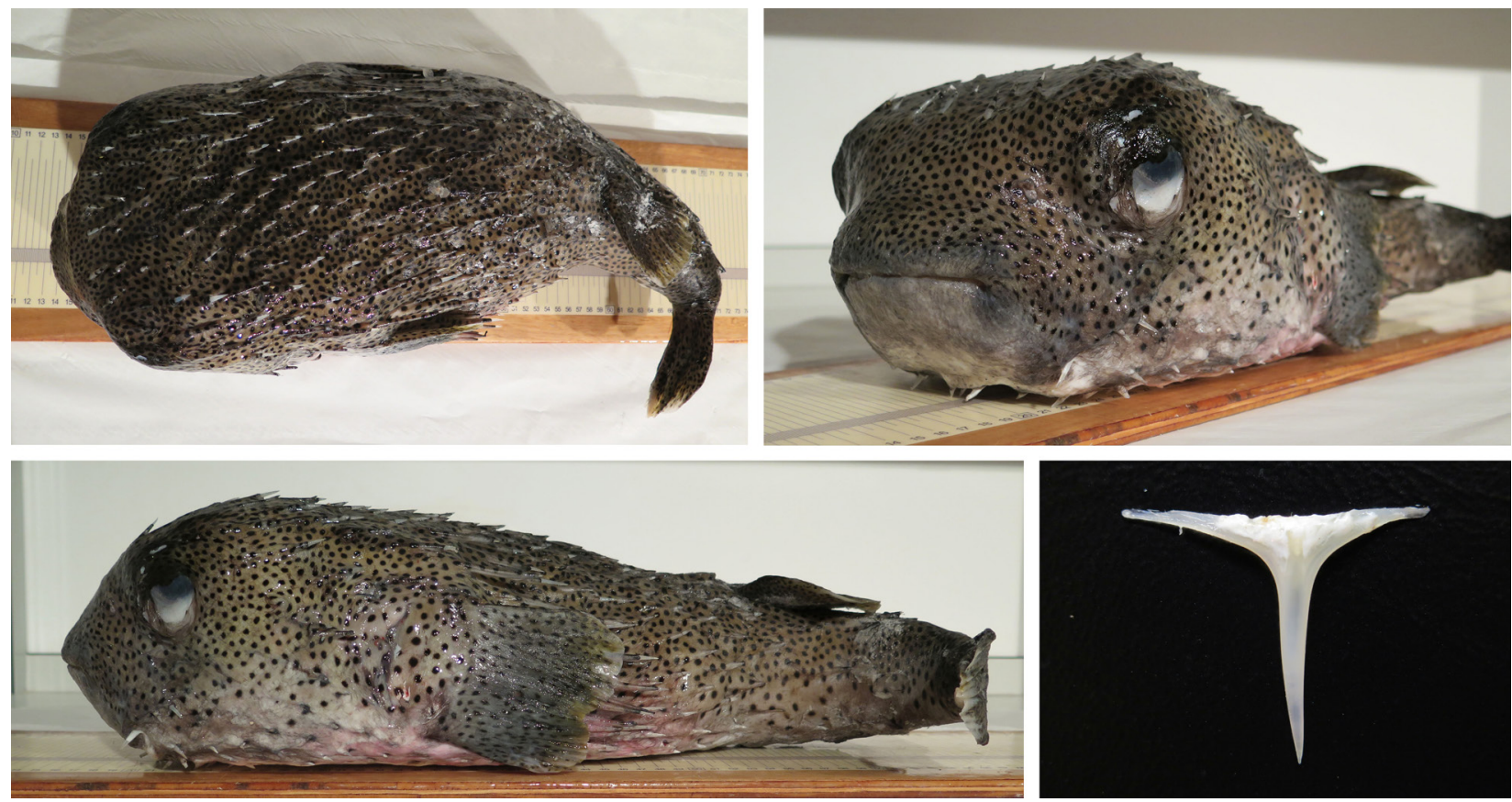

Fig. 2. Dorsal, anterior, and lateral views of the Diodon hystrix individual described in the presently reported new record of the species from Menorca (Balearic Islands, western Mediterranean); a detailed photograph of a two-rooted erectile body spine is also shown

According to the available literature, the presently reported finding is the second confirmed record of Diodon hystrix in the Mediterranean Sea. There has been a time lag of 55 years between the first and second record suggesting either that the species only reaches the Mediterranean Sea occasionally or that the species is commonly present but not detected due to its low abundance. The presently described record is coincident with an increase in the frequency of recent new records of Diodontidae in the north-eastern Atlantic and Mediterranean such as those of Diodon holocanthus Linnaeus, 1758 (see Porteiro et al. 2010) and Diodon eydouxii (see Azevedo et al. 2004, Barreiros and Fricke 2015) from the Azores Archipelago and Chilomycterus reticulatus (see Follesa et al. 2009) and the Lessepsian migrant $C$. spilostylus (see Erguden et al. 2012) from Sardinia and southern Turkey, respectively, in the Mediterranean. The recently observed global warming may be allowing Diodontidae species, mainly adapted to live in warm temperate and tropical waters (Leis 2006), to extend their distribution range. Particularly, the increase of water temperature in the Mediterranean (Vargas-Yáñez et al. 2005) may be favouring the adaptation and extension not only of Diodontidae but also other Tetraodontiformes such as the tetraodontid fish Lagocephalus sceleratus (Gmelin, 1789). The latter pufferfish entered in the Mediterranean through the Suez Canal and was recorded for the first time by Filiz and Er (2004) from the southern Aegean Sea, subsequently undergoing a population explosion in the Mediterranean Levant basin and a rapid expansion to the west (Kara et al. 2015). At the moment the scarce information on $D$. hystrix does not allow to assess whether a well-established population is present in the Mediterranean and if it has the potential to become more abundant as reported for the Lessepsian migrant L. sceleratus. Diodon hystrix is a large fish, reaching $90 \mathrm{~cm}$ in standard length (Tortonese 1986) and it is considered one of the most powerful shell-crushing predators of molluses and some crustaceans including hermit crabs on tropical coasts of the world (Vermeij and Zipser 2015). Therefore its establishment in the Mediterranean Sea could have important consequences not only for its main preys but also for the indigenous competitors that feed on the same trophic resources. The size of the individual reported in the present paper is far above the size at which $D$. hystrix starts to feed on benthic species (23 cm; Leis 1978, Vermeij and Zipser 2015), so it can be expected that the individual was able to feed actively off the coasts of Menorca. Hence, monitoring its potential population growth in the Mediterranean Sea is of particular importance.

Regarding the monitoring of Diodon hystrix and, in general, other non indigenous species in the Mediterranean, besides the information from the commercial fleets, it may be of high importance the information on catches from recreational fishermen, which can provide an early detection of the arrival of these species (Azzurro et al. 2013, 2018, Banha et al. 2015). This may be particularly important when the species have low catchability with commercial gears and/or in areas where the recreational fishery has turned to be as important in catches as the commercial fleet, as it is the case of the Balearic Islands (Morales-Nin et al. 2015).

Finally, we would like to emphasize the dynamics of the record reported here. The specimen described in this paper was caught during a spearfishing competition. A spearfisher that was following the competition results 
through social networks immediately contacted the authors of this publication by sending a picture via WhatsApp instantaneous messenger along with the information of the place of the competition, which allowed us to rapidly find and collect it. Future collaborations between researchers and recreational fishermen should be fostered, in particular in the context of social networks, as it could help in the early detection of the arrival of new non-indigenous species to the Mediterranean.

\section{ACKNOWLEDGEMENTS}

Thanks are expressed to the spearfisher who provided information on the capture of Diodon hystrix.

\section{REFERENCES}

Akşıray F. 1954. Türkiye deniz balıkları, tâyin anahtarı. [Marine fishes of Turkey, an identification key.] İstanbul Üniversitesi, Fen Fakültesi, Hidrobiologi Araştırma, Enstitüsü Yayınlarından, Istanbul, Turkey. [In Turkish.]

Azevedo J.M.N., Raposeiro P.M., Rodrigues L. 2004. First record of Fistularia petimba and Diodon eydouxii for the Azores, with notes on the occurrence of three additional species. Journal of Fish Biology 65 (4): 1180-1184. DOI: 10.1111/j.0022-1112.2004.00523.x

Azzurro E., Bolognini L., Dragičević B., Drakulović D., Dulčić J., Fanelli E., Grati F., Kolitari J., Lipej L., Magaletti E., Marković O., Matić-Skoko S., Mavrič B., Milone N., Joksimović A., Tomanić J., Scarpato A., Tutman P., Vrdoljak D., Zappacostah F. 2018. Detecting the occurrence of indigenous and nonindigenous megafauna through fishermen knowledge: A complementary tool to coastal and port surveys. Marine Pollution Bulletin (in press). DOI: 10.1016/j. marpolbul.2018.01.016

Azzurro E., Broglio E., Maynou F., Bariche M. 2013. Citizen science detects the undetected: The case of Abudefduf saxatilis from the Mediterranean Sea. Management of Biological Invasions 4 (2): 167-170. DOI: $10.3391 / \mathrm{mbi} .2013 .4 .2 .10$

Banha F., Ilhéu M., Anastácio P.M. 2015. Angling web forums as an additional tool for detection of new fish introductions: the first record of Perca fluviatilis in continental Portugal. Knowledge and Management of Aquatic Ecosystems 2015 (416): e03. DOI: 10.1051/ $\mathrm{kmae} / 2014039$

Barreiros J., Fricke R. 2015. Occurrence of Diodon eydouxii (Actinopterygii: Tetraodentiformes: Diodontidae) in the Azores and comparison with Pacific specimens. Acta Ichthyologica et Piscatoria 45 (1): 101-102. DOI: 10.3750/AIP2015.45.1.12

Bilecenoglu M., Taskavak E., Mater S., Kaya M. 2002. Checklist of the marine fishes of Turkey. Zootaxa 113 (1): 1-194. DOI: 10.11646/zootaxa.113.1.1

Brito A., Pascual P.J., Falcón J.M., Sancho A., González G. 2002. Peces de las Islas Canarias. Catálogo comentado e ilustrado. Francisco Lemus, Tenerife, Spain. di Noronha A.C., Sarmento A.A. 1948. Vertebrados de Madeira. [Vertebrates of Madeira.] Volume 2. Junta Geral do Distrito Autónomo do Funchal, Funchal, Portugal. [In Portuguese.]

Dollfus R.P. 1955. Première contribution a l'établissement d'un fichier ichthyologique du Maroc atlantique de Tanger à l'embouchure de l'Oued Dra. Travaux de l'Institut Scientifique Chérifien, Série Zoologie 6: 1-227.

Ellis J.R. 2006. Occurrence of exotic fishes in East Anglian waters: Porcupinefish Diodon hystrix and piranha Pygocentrus sp. Transactions of the Suffolk Natural Society 42: 39-42.

Erguden D., Bayhan Y.K., Turan C. 2012. First record of spotbase burrfish, Cyclichthys spilostylus (Actinopterygii: Tetraodontiformes: Diodontidae), from the marine waters of Turkey. Acta Ichthyologica et Piscatoria 42 (2): 137-140. DOI: 10.3750/ AIP2011.42.2.07

Fricke R., Eschmeyer W.N., van der Laan R. (eds.) 2018. Catalog of fishes: Genera, species, references. California Academy of Sciences, San Francisco, USA. [Accessed on 11 December 2018.] http://researcharchive.calacademy.org/research/ ichthyology/catalog/fishcatmain.asp

Evans J., Barbara J., Schembri P.J. 2015. Updated review of marine alien species and other 'newcomers' recorded from the Maltese Islands (Central Mediterranean). Mediterranean Marine Science 16 (1): 225-244. DOI: 10.12681/mms. 1064

Filiz H., Er M. 2004. Akdeniz'in yeni misafiri. [New guests in the Mediterranean Sea.] Deniz Magazin 3 (68): 52-54. [In Turkish.]

Follesa M.C., Mulas A., Porcu C., Cau A. 2009. First record of Chilomycterus reticulatus (Osteichthyes: Diodontidae) in the Mediterranean Sea. Journal of Fish Biology 74 (7): 1677-1681. DOI: 10.1111/j.10958649.2009.02229.x

Galil B.S., Boero F., Campbell M.L., Carlton J.T., Cook E., Fraschetti S., Gollasch S., Hewitt C.L., Jelmert A., Macpherson E., Marchini A., McKenzie C., Minchin D., Occhipinti-Ambrogi A., Ojaveer H., Olenin S., Piraino S., Ruiz G.M. 2015. 'Double trouble': The expansion of the Suez Canal and marine bioinvasions in the Mediterranean Sea. Biological Invasions 17 (4): 973-976. DOI: 10.1007/s10530-0140778-y

Garrido A., Ibáñez-Yuste A.J., Norman C., TerrónSigler A. 2014. First record of Chilomycterus spinosus mauretanicus (Osteichthyes: Diodontidae) in the Mediterranean Sea. Marine Biodiversity Records 7: e79. DOI: $10.1017 /$ S1755267214000530

Golani D. 1993. Trophic adaptation of Red Sea fishes to the eastern Mediterranean environment-Review and new data. Israel Journal of Zoology 39 (4): 391-402.

Golani D., Orsi-Relini L., Massuti E., Quignard J.-P., Dulčić J., Azzurro E. 2017. CIESM atlas of exotic species in the Mediterranean. Vol. 1. Fishes. CIESM Publishers, Monaco. 
Gonçalves B.C. 1941. Collecção oceanográfica de D. Carlos I. Catálogo de peixes. [Oceanographic collection of king Carlos I. Catalog of fishes.] Travaux de la Station de Biologie Maritime de Lisbonne 46: 1-108. [In Portuguese.]

Kara M.H., Ben Lamine E., Francour P. 2015. Range expansion of an invasive pufferfish, Lagocephalus sceleratus, (Actinopterygii: Tetraodontiformes: Tetraodontidae), to the south-western Mediterranean. Acta Ichthyologica et Piscatoria 45 (1): 103-108. DOI: $10.3750 / A I P 2015.45 .1 .13$

Leis J.M. 1978. Systematics and zoogeography of the porcupinefishes (Diodon, Diodontidae, Tetraodontiformes), with comments on egg and larval development. Fisheries Bulletin 76 (3): 535-567.

Leis J.M. 2001. Diodontidae. Porcupinefishes (burrfishes). Pp. 3958-3965. In: Carpenter K.E., Niem V. (eds.) FAO species identification guide for fishery purposes. The living marine resources of the western central Pacific. Vol. 6. Bony fishes. Part 4 (Labridae to Latimeriidae), estuarine crocodiles. FAO, Rome.

Leis J.M. 2006. Nomenclature and distribution of the species of the porcupinefish family Diodontidae (Pisces, Teleostei). Memoirs of Museum Victoria 63 (1): 77-90.

Leis J.M. 2016. Diodontidae. Porcupinefishes (burrfishes, spiny puffers). Pp. 3074-3079. In: Carpenter K.E., de Angelis N. (eds.) The living marine resources of the Eastern Central Atlantic. Volume 4. Bony fishes part 2 (Perciformes to Tetradontiformes) and Sea turtles. FAO Species Identification Guide for Fishery Purposes. FAO, Rome.

Lozano y Rey L. 1952. Peces fisoclistos, subserie toracicos, primera parte. Memorias de la Real Academia de Ciencias Exactas, Físicas y Naturales de Madrid, Serie de Ciencias Naturales 14 (1): i-Xv + 1-378, pls. 1-30.

Morales-Nin B., Cardona-Pons F., Maynou F., Grau A.M. 2015. How relevant are recreational fisheries? Motivation and activity of resident and tourist anglers in Majorca. Fisheries Research 164: 45-49. DOI: 10.1016/j.fishres.2014.10.010

Parmesan C., Yohe G. 2003. A globally coherent fingerprint of climate change impacts across natural systems. Nature 421 (6918): 37-42.

Porteiro F.M., Menezes G.M., Afonso P., Monteiro J.G., Santos R.S. 2010. Marine fish (Chondrichthyes, Actinopterygii). Pp. 325-345. In: Borges P.A.V., Costa A., Cunha R., Gabriel R., Gonçalves V., Martins A.F., Melo I., Parente M., Raposeiro P., Rodrigues P., Santos R.S., Silva L., Vieira P., Vieira V. (eds.) A list of the terrestrial and marine biota from the Azores. Principia, Cascais, Portugal.
Relini L.O. 2010. Non native marine fish in Italian waters. Pp. 267-292. In: Golani D., Appelbaum-Golani B. (eds.) Fish invasion of the Mediterranean Sea: Changes and renewal. Pensoft Publishers, Sofia-Moscow.

Rilov G., Galil B. 2009. [Chapter 31] Marine bioinvasions in the Mediterranean Sea-History, distribution and ecology. Pp. 549-575. DOI: 10.1007/978-3-54079236-9_31 In: Rilov G., Crooks J.A. (eds.) Biological invasions in marine ecosystems. Springer-Verlag, Berlin-Heidelberg, Germany. DOI: 10.1007/978-3540-79236-9

Santos R.S., Porteiro F.M., Barreiros J.P. 1997. Marine fishes of the Azores: An annotated checklist and bibliography: A catalogue of the Azorean Marine ichthyodiversity. Arquipélago - Life and Marine Sciences. Bulletin of the University of the Azores, Supplement 1. Universidade dos Açores, Horta, Açores, Portugal.

Sunday J.M., Bates A.E., Dulvy N.K. 2012. Thermal tolerance and the global redistribution of animals. Nature Climate Change 2 (9): 686-690. DOI: 10.1038/ nclimate1539

Torchio M. 1963. Accertata presenza di un rappresentante della famiglia Diodontidae in Mediterraneo. [The established presence of a representative of the family Diodontidae in the Mediterranean.] Atti della Società Italiana della Scienze Naturali 102 (3): 277-281. [In Italian.]

Tortonese E. 1986. Diodontidae. Pp. 1346-1347. In: Whitehead P.J.P., Bauchot M.-L., Hureau J.-C., Nielsen J., Tortonese E. (eds.) Fishes of the northeastern Atlantic and Mediterranean. Vol. 3. UNESCO, Paris.

Vargas-Yáñez M., Salat J., Fernández de Puelles M.L., López-Jurado J.L., Pascual J., Ramírez T., Cortés D., Franco I. 2005. Trends and time variability in the northern continental shelf of the western Mediterranean. Journal of Geophysical Research 110 (C10): C10019. DOI: 10.1029/2004JC002799

Vermeij G.J., Zipser E. 2015. The diet of Diodon hystrix (Teleostei: Tetraodontiformes): Shell-crushing on Guam's Reefs. Bishop Museum Bulletin in Zoology 9: $169-175$.

Zenetos A., Gofas S., Verlaque M., Çinar M.E., García Raso J.E., Bianchi C.N., Morri C., Azzurro E., Bilecenoglu M., Froglia C., Siokou I., Violanti D., Sfriso A., San Martin G., Giangrande A., Katağan T., Ballesteros E., Ramos-Esplá A., Mastrototaro F., Ocaña O., Zingone A., Gambi M., Streftaris N. 2012. Alien species in the Mediterranean Sea by 2010. A contribution to the application of European Union's Marine Strategy Framework Directive (MSFD). Part I. Spatial distribution. Mediterranean Marine Science 11 (2): 381-493. DOI: $10.12681 / \mathrm{mms} .87$

Received: 8 April 2018 Accepted: 4 August 2018 Published electronically: 31 December 2018 